This is an author produced version of a paper published in Analytical Biochemistry. This paper has been peer-reviewed but does not include the final publisher proofcorrections or journal pagination.

Citation for the published paper:

Teilum, $\mathrm{M}$ and Hansson, $\mathrm{M} \mathrm{J}$ and Dainiak, $\mathrm{M} \mathrm{B}$ and Mansson, R and Surve, S and Elmér, E and Onnerfjord, P and Mattiasson, G "Binding mitochondria to cryogel monoliths allows detection of proteins specifically released following permeability transition."

Anal Biochem. 2006 Jan 15;348(2):209-21.

http://dx.doi.org/10.1016/j.ab.2005.08.032

Access to the published version may require journal subscription.

Published with permission from: Elsevier 


\title{
Binding mitochondria to cryogel monoliths allow detection of proteins specifically released following permeability transition
}

\author{
M Teilum ${ }^{1}{ }^{*}$, MJ Hansson ${ }^{1}$, MB Dainiak ${ }^{2,3}$, R Månsson ${ }^{1}$, S Surve ${ }^{4}$, E Elmér $^{1}$, \\ P Önnerfjord ${ }^{4}, G_{\text {Mattiasson }}{ }^{1}$
}

\begin{abstract}
Following proapoptotic signals such as calcium-induced mitochondrial permeability transition or translocation of proapoptotic proteins, mitochondria induce cell death through release of apoptogenic proteins. The mechanism of release and the identity of the released proteins are currently debated. Earlier attempts at identification of the apoptogenic proteins have been hampered by a high non-specific background.

Our aim was to develop a novel method where background release was eliminated allowing proteins specifically released from mitochondria following proapoptotic stimulation to be identified. Liver mitochondria were immobilized and washed on cryogel monoliths prior to induction of protein release (calcium or Bid/Bax). Immobilized mitochondria exhibited normal morphology and swelling response, as well as retained respiratory activity.

The released proteins were collected, concentrated, separated on polyacrylamide gels which were cut into pieces, trypsindigested and analyzed using LC-MS/MS. Control samples contained no protein, and stimulation with calcium and $\mathrm{Bid} / \mathrm{Bax}$ resulted in identification of 68 and 82 proteins, respectively. We conclude that in combination with the robust proteomic approach, immobilization on cryogel monoliths is a fruitful approach for studying specific protein release from isolated mitochondria. We propose that this method is a powerful tool to further characterize the role of mitochondria in cell death induction.
\end{abstract}

Keywords ATP; apoptosis; cell death; LC-MS/MS; mass spectroscopy; scanning electron microscopy; transmission electron microscopy; tBid; Bax.

The principal function of mitochondria is to synthesize ATP through oxidative phosphorylation. Mitochondria are also important for maintaining the tight control of intracellular calcium levels, which is essential for higher organisms. Given these central functions it is not surprising that even small alterations of mitochondrial physiology can lead to disease; the outcome of which can be very different. Over the last decades, it has dawned that in addition to its ATP producing and calcium regulating functions, mitochondria play an important role in intracellular signalling cascades leading to death or survival of the cell in conditions such as hepatotoxicity, ischemia reperfusion damage of brain and heart, cancer and HIV infections [1,2]. Several mechanisms of mitochondrial involvement in cell death have been proposed, for example increased oxidative stress, altered calcium homeostasis, impairment of respiratory chain complexes, and- more recently- the activation of the mitochondrial permeability transition pore (mPTP); a pore in the mitochondrial membrane bilayer formed by a multi-protein complex. The complex consists largely of voltage dependent anion channel (VDAC), situated in the outer mitochondrial membrane, adenine nucleotide translocator (ANT), situated in the inner mitochondrial membrane, and cyclophilin D, a soluble molecule found in the matrix [3].

\footnotetext{
*Corresponding author. Email adress: maria.teilum@med.lu.se

Abbreviations used: $\mathrm{mPTP}$, mitochondrial permeability transition pore; ANT, adenine nucleotide translocator; mPT, mitochondrial permeability transition;PA, polyacrylamide; IDA, iminodiacetic acid; IB, incubation buffer; BSA, bovine serum albumin; MOPS, 4-morpholinepropanesulfonic acid; SEM,Scanning electron microscopy; TEM, transmission electron microscopy; o.n., overnight; TFA, trifuoroacetic acid; MALDI, matrixassisted laser desorption ionization; TOF, time of flight; TEMED, Tetramethylethylenediamine.
} 
Opening of the pore disrupts the proton gradient, and thus uncouples oxidative phosphorylation. Activation of the $\mathrm{mPTP}$ renders the inner membrane permeable to substances $\leq 1500 \mathrm{Da}[4]$, leading to osmotic swelling due to the large amount of proteins present in the mitochondrial matrix, and eventually to disruption of the outer membrane with concomitant release of a number of factors from the mitochondrial intermembrane space and matrix into the cytoplasm [5]. The principal activator of the $\mathrm{MPTP}$ is calcium; the concentration required depends on the surrounding conditions. Mitochondrial permeability transition $(\mathrm{mPT})$ can be induced by increased calcium concentration in vivo $[6,7]$ as well as in vitro $[8-11]$ and may be reversed by removing calcium [9] or prevented by the administration of inhibitors of $\mathrm{mPTP}$, such as cyclosporin $\mathrm{A}$ or its non-immunosuppressive analogues [12]. In the experimental setting, membrane permeabilisation can be achieved by drugs such as the mPTP inducer atractyloside or the ionophore alamethicin. The physiological role of the $\mathrm{mPT}$, if any, is not known, but it has been suggested to have a role in calcium homeostasis (reviewed by [11]). Pathophysiological activation of $\mathrm{mPTP}$ has recently been convincingly demonstrated to be critical in ischemia/reperfusion injury and essential to calcium- or oxidative stress-induced cell death. However the mPTP seemed to be of lesser importance to apoptotic cell death during normal development and to apoptosis regulated by proteins of the Bcl-2 family [13, 14]. As shown by Morin et al, cytochrome c release from liver mitochondria occurs independently of mPTP during ischemia, whereas it occurs dependent on $\mathrm{mPT}$ in the reperfusion interval [7]. $\mathrm{mPT}$ thus has different importance in different settings.

Mitochondrial protein release can also be stimulated by proapoptotic members of the $\mathrm{Bcl}-2$ family of proteins (e.g. Bax, $\mathrm{tBid}$ ); these proteins are generally regarded to mainly induce selective outer membrane permeabilisation independent of $\mathrm{mPT}$ [15]. Unlike the anti-apoptotic $\mathrm{Bcl}-2$ proteins, which appear to be exclusively membrane bound, their proapoptotic counterparts (e.g. Bax, Bad, Bim, Bmf) are mainly localized in the cytosol or associated with cytoskeletal proteins under nonapoptotic conditions [16]. Following a death signal, these proteins translocate to mitochondria, where they regulate the activity of the $\mathrm{Bcl}-2$ proteins. Under normal conditions, Bax predominantly exists as a monomeric protein and has cytosolic distribution, but following activation during cell death, Bax translocates to the mitochondria [17], and induces homodimerization [18-20]. Bax then integrates in the outer mitochondrial membrane, and causes release of proteins from the intermembrane space, e.g. cytochrome c $[21,22]$, which triggers apoptosis. In addition to $\mathrm{Bax}$, the $\mathrm{BH} 3$-only proapoptotic proteins, e.g. Bid, translocate from the cytosol to the mitochondria following activation. Bid is activated by cleavage of its amino terminus by caspase- 8 during TNF $\alpha$ - or Fas-induced cell death to form the truncated version $\mathrm{tBid}$, which can interact with $\mathrm{Bax}$ or Bak to facilitate its oligomerization [23-25] .

Currently, only a limited number of the proteins released from mitochondria upon e.g. calcium-induced $\mathrm{mPT}$ or following stimulation with proapoptotic $\mathrm{Bcl}-2$ proteins are known. Examples of released factors are apoptosis inducing factor (AIF), cytochrome c, SMAC/DIABLO, and hsp10 [5]. These factors may participate in the activation of cell death programs in several different cell types. It is currently not known if induction of mitochondrial protein release by calcium or proapoptotic Bax results in the release of the same or similar proteins, i.e. if the pathway of cell death is identical downstream of mitochondrial protein release. It could be speculated that the inducer of $\mathrm{mPT}$ determines which proteins are released, but so far no conclusive studies have been performed on this subject. Attempts at identifying proteins released following mPTP or selective outer membrane permeabilisation induced by truncated Bid (tBid) in vitro, have been performed during the last years [26-28]. However, several of these studies encountered the obstacle that non-specific leakage of proteins from mitochondria, probably caused e.g. by mitochondrial rupture following repeated centrifugations and resuspensions, is very high in vitro. The high non-specific background contaminates the proteins that were specifically released, making identification of specifically released proteins very difficult.

To identify the proteins that are released, it is helpful to apply open-approaches, i.e. to include all proteins independent of their physical characteristics (e.g. size, isoelectric point (pI)). The recent advances within the proteomics field have provided the necessary tools, and reports of open-approaches looking for proteins released from mitochondria have been published [26-29]. To identify individual proteins in a complex mixture, several proteomics-based approaches have become available lately. In general, these strategies are composed of a separation and an identification step. The traditional way to separate complex protein mixtures is by $2 \mathrm{D}$ gel electrophoresis, but this method is problematic for mitochondrial proteins, since they often have extreme pI [30, 31]. Alternative methods of separation are by $1 \mathrm{D}$ polyacrylamide (PA) gel electrophoresis or by liquid chromatography (LC). As these techniques do not rely on $\mathrm{pI}$, they are preferable for separation of mitochondrial proteins. Identification of proteins from tryptic peptide fragments can be performed using mass spectrometry (MS), as in peptide mass fingerprinting, or tandem mass spectrometry (MS/MS) where selected peptide ions are fragmented, allowing sequence information from that particular peptide to be obtained.

The objective of the present study was to establish a method, which would allow collection of specifically 
released proteins, i.e. reduce the high non-specific background. To achieve this, we used cryogel monoliths (denoted monoliths hereafter), which is a sponge-like material composed of large $(10-100 \mu \mathrm{m})$ interconnected pores [32], to bind mitochondria. The poly(acrylamide)-based continuous macroporous structure and non-adhesive properties of the polyacrylamide-based pore walls allow for free passage of bio-nanoparticulates (inclusion bodies, viruses, cells etc.) through plain monoliths in the absence of affinity interactions with the matrix $[32,33]$. These properties make monolithic adsorbents highly suitable for the processing of particulate-containing samples. Affinity monoliths have previously been exploited for the fractionation of different types of mammalian [34] and bacterial [35] cells, affinity capture of viruses [36] and for integrated capture/purification of recombinant proteins from non-clarified cell culture fluids [37, 38]. Chelating affinity monoliths with immobilised $\mathrm{Cu} 2+$ will bind mitochondria, most likely through histidineresidues on their surface.

The objective of the present study was to establish a method, which would allow detection of proteins released specifically from mitochondria following stimulation with agents known to promote mitochondria permeabilisation. To achieve this, mitochondria were attached to monoliths, unspecific proteins were washed away, and mitochondria were subjected to calcium or a combination of Bid and Bax in doses that resulted in large amplitude swelling in mitochondria in suspension [9]. We demonstrate that proteins specifically released from mitochondria can be isolated and identified without the problem of a high background of unspecifically released proteins. This novel method may serve as a valuable tool to analyze pathways of mitochondrial signalling in this and other systems.

\section{Materials and Methods}

\section{Materials}

Percoll was purchased from Pharmacia; all other chemicals were ultra grade and purchased from SigmaAldrich, and its associated suppliers. Recombinant mouse Bid (75-195) and Bax (38-171), both truncated to increase efficiency [39] were purchased from ProteinX lab (USA).

\section{Cryogel monolith preparation}

Epoxy-activated monoliths were produced as previously described [37]. In brief, epoxy-activated monoliths (plugs $12.5 \times 7.1 \mathrm{~mm}$ ) were produced using 3.5\% solution of co-monomers (Acrylamide, N,N`methylenebis(acrylamide), and allyl glycidyl ether) in the reaction mixture with ammonium persulfate and TEMED as initiators. Coupling IDA ligands to epoxy activated monoliths was carried out according to [37]. The amount of chelate groups was determined to be 13 $\mu \mathrm{mol} / \mathrm{ml}$ adsorbent by assaying the amount of bound $\mathrm{Cu} 2+$ ions.

\section{Mitochondria preparation}

Mitochondria were isolated from rat liver tissue using differential centrifugation according to Halestrap and colleagues [40] with slight modifications [10]. Animal procedures were approved by the Malmö/Lund Ethical Committee for Animal Research (M224-03). Adult male Wistar rats, 350 - 450 g, were briefly sedated with halothane and euthanized by decapitation. The liver was rapidly removed and put into ice-cold isolation buffer (IB) $(320 \mathrm{mM}$ Sucrose, $2 \mathrm{mM}$ EGTA, $10 \mathrm{mM}$ Tris, $\mathrm{pH}$ 7.2). Homogenization of liver tissue was performed in IB $(10 \% \mathrm{w} / \mathrm{v})$ containing $0.5 \%$ BSA using a $10 \mathrm{ml}$ Kontes Teflon Homogenizer, size 22. The homogenate was centrifuged in a Beckman Avanti Centrifuge with $\mathrm{F} 1010$ rotor at $311 \mathrm{x} \mathrm{g}$ for $10 \mathrm{~min}$ at $4^{\circ} \mathrm{C}$. The supernatant was decanted and centrifuged at 7,800 x g for $5 \mathrm{~min}$. The resulting pellet was resuspended in IB with $19 \%$ Percoll in order to remove contaminating membranes and centrifuged at 11,220 $\mathrm{x}$ g for $10 \mathrm{~min}$. A last washing step of the pellet was performed in IB at $7,800 \mathrm{x}$ g for $5 \mathrm{~min}$ and the final pellet was resuspended in a small volume of IB. The concentration of mitochondrial protein was determined by the Bradford method using BSA as standard [41]. Prior to use, the mitochondria were diluted in swelling buffer $(250 \mathrm{mM}$ sucrose, $20 \mathrm{mM}$ MOPS, $10 \mathrm{mM}$ Tris, $2 \mathrm{mM} \mathrm{K2PO4,} 1$ $\mathrm{mM} \mathrm{MgCl} 2,1 \mu \mathrm{M}$ EGTA, $\mathrm{pH}$ 7.2) to yield the desired concentration. This protocol results in a mitochondrial preparation essentially free of contaminating organelles, such as endoplasmatic reticulum [9]. All experiments were conducted within 6 hours of decapitation of the rats. A total of 6 rat livers were used for the final protein release experiments using calcium to induce $\mathrm{mPTP}$. A seventh liver was used for identification of $\mathrm{Bid} / \mathrm{Bax}$ released proteins.

Detection of mitochondrial permeability transition pore activation

Activation of mitochondrial permeability transition was monitored as described previously [10] by measuring the decrease in $90^{\circ}$ light scattering at $520 \mathrm{~nm}$ (mitochondrial swelling) using a Perkin-Elmer Spectrometer LS-50B. The decrease in light scattering closely parallels the percentage of the mitochondrial population undergoing permeability transition [42].

\section{Calcium-stimulated release of proteins in suspension}

To induce $\mathrm{mPT}$ in suspension, mitochondria (approx. 2 $\mathrm{mg}$ ) were pre-incubated in swelling buffer containing 5 $\mathrm{mM}$ malate and $5 \mathrm{mM}$ glutamate for two minutes, and stimulated with $2 \mu \mathrm{mol} \mathrm{CaCl} 2$ per mg mitochondria for $8 \mathrm{~min}$ at $37^{\circ} \mathrm{C}$. After $5 \mathrm{~min}$ of incubation, a protease inhibitor cocktail ("General use", Sigma) was added. The protease inhibitors were not added from start, because it has been suggested that release of some 
proteins following $\mathrm{mPT}$ may depend on protease activity [43]. The sample was centrifuged at 7,000 x g for $7 \mathrm{~min}$, followed by centrifugation of the supernatant at $20,000 \mathrm{xg}$ for $15 \mathrm{~min}$, and the resulting supernatant was stored at $-80^{\circ} \mathrm{C}$ until further processing.

\section{Calcium-stimulated release of proteins on cryogel monoliths}

To bind mitochondria, monoliths $(12.5 \times 7.1 \mathrm{~mm}$ diameter) were inserted into the wells of a 96-well microtiter plate with open-ended wells, conditioned with 6 volumes ( 1 volume $=0.5 \mathrm{~mL}$ ) of $0.25 \mathrm{M} \mathrm{CuSO} 4$, washed with milliQ $\mathrm{H} 2 \mathrm{O}$, and equilibrated with 6 volumes of monolith swelling buffer (CS-buffer) (250 $\mathrm{mM}$ sucrose, $20 \mathrm{mM}$ MOPS, $10 \mathrm{mM}$ Tris, $2 \mathrm{mM}$ K2PO4, $1 \mathrm{mM} \mathrm{MgCl}$, $10 \mathrm{mM}$ imidazole, $5 \mathrm{mM}$ malate, $5 \mathrm{mM}$ glutamate, $\mathrm{pH}$ 7.2) at room temperature. Imidazole was included in the swelling buffer to reduce binding of both mitochondria and released proteins to the monolith surface, as initial studies had shown that the binding of mitochondria to monoliths was very strong. $1.5 \mathrm{mg}$ mitochondria were suspended in $250 \mu \mathrm{l}$ CS buffer and loaded on a monolith. Following $6 \mathrm{~min}$ of incubation, the monoliths were washed with 10 volumes of CS buffer. After quantifying the amount of mitochondria in the eluate by Bradford as well as light scattering at $520 \mathrm{~nm}$, the eluate was discarded.

To induce mPT in the mitochondria, $300 \mu$ CS buffer, containing $8 \mu \mathrm{mol} \mathrm{CaCl} 2$ per $\mathrm{mg}$ mitochondria, was loaded on the monoliths, and incubated for $8 \mathrm{~min}$. This dose resulted in swelling of a majority of mitochondria bound to monoliths as verified by electron microscopy (see below). The released proteins were eluted into a 96 well plate containing protease inhibitor cocktail (“General use", SigmaAldrich) using 2 volumes of CS buffer. The eluates were centrifuged (7,000 x g, $7 \mathrm{~min}$, followed by $20,000 \times \mathrm{g}, 15 \mathrm{~min}$ ), and the resulting supernatant was stored at $-80^{\circ} \mathrm{C}$ until further processing. See figure 1 for illustration of approach.

\section{Bid and Bax stimulated release of proteins on cryogel} monoliths

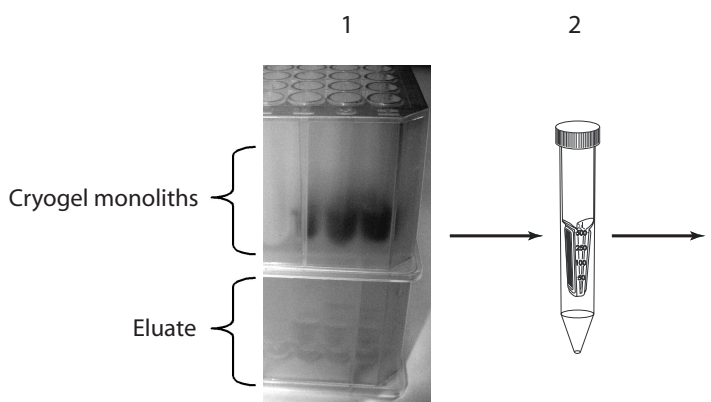

Protein release by Bid and Bax was performed essentially as for calcium-stimulated release. $1 \mathrm{mg}$ mitochondria were loaded on each monolith and CS buffer containing $5 \mu \mathrm{g} / \mathrm{mL}$ of each of Bid and Bax were added following washing with 10 volumes of CS buffer. Incubation proceeded for $60 \mathrm{~min}$ to induce permeabilization of the mitochondria.

\section{Electron microscopy}

Mitochondria were bound to monoliths, and subjected to i) control conditions ( $\mathrm{CaCl} 2$ free CS-buffer), ii) 8 $\mu \mathrm{mol} \mathrm{CaCl} 2 / \mathrm{mg}$ of mitochondrial protein in CSbuffer, or iii) alamethicin $(0.167 \mu \mathrm{g} / \mu \mathrm{l})$ in CS-buffer as described above. Bid/Bax treated mitochondria were not examined by electron microscopy. Following elution of released proteins, the mitochondria were fixed by passing 1 volume of fixing solution (1.5\% paraformaldehyde, $1.5 \%$ glutaraldehyde in Sørensen buffer $(0.1 \mathrm{M}$ phosphate buffer)). The monoliths were gently removed from the 96 well plate and left in fixing solution for $1 \mathrm{~h}$ at room temp, and overnight (o.n.) at 4 ${ }^{\circ} \mathrm{C}$ followed by washing to remove the fixing solution (twice; Sørensen buffer). Further fixing was performed in $1 \%$ OsO4 in cacodylate buffer ( $1 \mathrm{~h}$, room temp.), followed by dehydration in increasing concentrations of ethanol (25\%, 50\%, 75\% and Abs). For scanning electron microscopy (SEM) critical point drying, and sputter coating in gold/palladium was performed. SEM was performed on a JEOL JSM-5600LV scanning electron microscope. For transmission electron microscopy (TEM), samples were dehydrated in ethanol followed by acetone, and embedded in epon resin. Ultrathin sections $(50 \mathrm{~nm})$ were cut using a diamond blade, and stained with $2 \%$ uranyl acetate and lead citrate in a LKB ultrastainer. A JEOL JEM-1230 transmission electron microscope, coupled to a Gatan CCD-camera, was used for TEM.

\section{ATP assay}

Mitochondrial viability is commonly evaluated by determining phosphorylative coupling of respiratory activity, i.e. the ability to convert ADP to ATP in the

Figure 1.. Schematic illustration of approach. Mitochondria suspended in CS-buffer were loaded on cryogel monoliths, spontaneously released proteins were washed away, and the mitochondria were exposed to CS-buffer, or CS-buffer containing CaCl2 for 8 min or to $\mathrm{Bid} /$ Bax-containing CS buffer for $60 \mathrm{~min}$. (1). The released proteins were eluted from the monoliths by passing CS-buffer. The eluates were concentrated and buffer exchanged (2) using spin concentrators (Ultra4, millipore). $40 \mu \mathrm{g}$ protein from calcium samples were separated on a PA gel alongside control samples (3), and the PA gel was cut in pieces of approx. $7 \mathrm{~mm}$ (4). The gel pieces were subjected to in situ trypsin digestion and the generated peptides were extracted from the gels and analysed by LC-MS/MS (5). 
presence of substrate and oxygen. In mitochondria bound to monoliths, this ability was evaluated by measuring the amount of produced ATP in the eluates. Mitochondria were bound to monoliths in CS-buffer, unbound mitochondria were washed away, and mitochondria were subjected to incubation in $\mathrm{CaCl} 2$ free CS-buffer (control) or to $\mathrm{CaCl} 2$ containing CSbuffer for $8 \mathrm{~min}$. Subsequently the mitochondria were incubated with $2 \mathrm{mmol}$ ADP in CS-buffer for $8 \mathrm{~min}$. This buffer was displaced by two volumes of CS-buffer, the eluate was collected and assayed for ATP content using an ATP determination kit (Molecular Probes) based on emission of bioluminescence from the luciferase-driven conversion of luciferin to oxyluciferin under ATP consumption. Bioluminescence was detected in a Packard Tri-Carb 2100TR liquid scintillation analyzer as described by the kit manufacturer.

ATP production from mitochondria in suspension was assayed in a similar way. Following $8 \mathrm{~min}$ exposure to $\mathrm{CaCl} 2$-free (control) or $\mathrm{CaCl} 2$ containing CS-buffer, 2 mmol ADP was added to the buffer and the mitochondria were allowed to produce ATP for $8 \mathrm{~min}$. Following removal of the mitochondria by centrifugation, the ATP content of the remaining supernatant was assayed.

\section{Processing of proteins}

Calcium released proteins from a total of $3 \mathrm{mg}$ mitochondria (i.e. eluate from 2 monoliths) were pooled and concentrated on Millipore ultra4 spin concentrators, and buffer exchanged to TE-buffer (10 $\mathrm{mM}$ Tris, 5 mM EDTA, $\mathrm{pH}$ 7.0). Eluates from Bid/Bax stimulated mitochondria ( $2 \mathrm{mg}$ total) were processed in a similar manner. Protein content was measured using the Lowry protein assay (DC protein assay, BioRad) using BSA as a standard. Depending on the protein concentration, 2-3 calcium treated samples were pooled resulting in $40 \mu \mathrm{g}$ protein per final sample. Equivalent volumes of control samples were pooled, and the protein content was found to be below the detection limit $(\sim 7$ $\mathrm{ng} / \mathrm{ul}$ ) for both $8 \mathrm{~min}$ and the $60 \mathrm{~min}$ concentrated control samples. For $8 \mathrm{~min}$ control and calcium treatment, the three replicates were produced from mitochondria purified from 6 individual rat livers. For $\mathrm{Bid} / \mathrm{Bax}$ only one sample, originating from one liver, was processed for protein identification.

Following standard procedures, the samples were loaded on a polyacrylamide gel (henceforward abbreviated "PA gel") (stacking gel $4 \%$ polyacrylamide, separation gel 10 $20 \%$ gradient polyacrylamide, BioRad), and run alongside an equivalent incubation sample as well as a Kaleidoscope Prestained Standard size marker (BioRad) until the bromphenolblue reached the bottom of the gel. The gels were stained in Coomassie G-250 for 2 hours and destained o.n. Pilot experiments showed that the protein levels in the control samples could not be detected or identified in the subsequent analyses, and these samples were therefore not processed further. The PA gel lanes were cut in pieces of approx. $6 \mathrm{~mm}$, resulting in 10 gel pieces per sample (see figure 1). Coomassie stain was removed from the gelpieces by washing ( $40 \%$ acetonitrile, $25 \mathrm{mM} \mathrm{NH} 4 \mathrm{CO} 3$ ), and the proteins were reduced $(10 \mathrm{mM}$ DTT in $25 \mathrm{mM}$ NH4HCO3, $\mathrm{pH}$ 7.8) and alkylated (25 mM iodoacetamide in $25 \mathrm{mM} \mathrm{NH} 4 \mathrm{HCO} 3)$. Reducing and alkylating agents were removed prior to o.n. digestion by trypsin $(0.10 \mu \mathrm{g}$ trypsin in $25 \mathrm{mM} \mathrm{NH} 4 \mathrm{HCO} 3)$. The digestion was terminated by adding $1 \%$ TFA, and peptides were extracted twice using 50\% Acetonitrile / $0.1 \%$ TFA, desalted on stagetips [44], dried, and dissolved in $10 \mu \mathrm{l} 0.1 \%$ formic acid. Samples were placed in glass QsertVials (Waters), and stored at $4{ }^{\circ} \mathrm{C}$.

\section{$L C-M S / M S$}

The digested proteins were separated on an UltiMate (LC-Packings) liquid chromatography system and identified using an Esquire HCT (Bruker Daltonics) ion-trap mass spectrometer. $4 \mu \mathrm{l}$ of the extracted peptides were analysed in each run. The reverse phase chromatography was run on a capillary column (Atlantis $\mathrm{dC} 18,150 \mu \mathrm{m} \times 150 \mathrm{~mm}, 3 \mu \mathrm{m}$, Waters) with a binary mobile phase gradient of $5-54.5 \% \mathrm{~B}$ in $33 \mathrm{~min}$ (A: water:acetonitrile $97: 3, \quad 0.1 \%$ formic acid, B: water:acetonitrile 20:80, 0.1\% formic acid). The flow rate was $2 \mu \mathrm{l} / \mathrm{min}$ and the column outlet was directly connected to the microflow nebulizer of the electrospray interface operating at a capillary voltage of $4000 \mathrm{~V}$. Using the same digested samples, the LC-MS/MS experiments were run twice with slight changes in the experimental conditions. The MS was always run in enhanced mode (scan speed $8,100(\mathrm{~m} / \mathrm{z}) / \mathrm{s}$ ) while the MS/MS was run either in enhanced or in ultrascan $(26,000(\mathrm{~m} / \mathrm{z}) / \mathrm{s})$ mode. The maximum number of ions in the trap was changed (ion charge control) from 200,000 (1st run) to 100,000 (2nd run), and the threshold was furthermore increased from 40,000 (1st run) to 100,000 (2nd run). The ion selection was set to exclude singly charged ions and to pick 2 precursors from each MS scan to perform MS/MS. Precursor ions were excluded from MS/MS sampling when 3 (1st run) or 2 (2nd run) MS/MS runs had been performed. The preferred target mass was set to $800 \mathrm{~m} / \mathrm{z}$ (1st run) or $700 \mathrm{~m} / \mathrm{z}$ (2nd run). For the LC, the same gradient was applied in both runs, but the run time was reduced from approx. $60 \mathrm{~min}$ to $45 \mathrm{~min}$ in the second run. Each region of the PA gel was thus analyzed twice in three replicates by LC-MS/MS.

\section{Data analyses}

The data was processed with Biotools software (Bruker Daltonics) and the resulting mascot generic files (mgf) were submitted for searches using web-accessible Mascot search algorithms (www.matrixscience.com), as well as an in-house version of Mascot. Searches were submitted to Swiss-Prot and NCBI databases. Database searching were made with the following parameters: 
peptide charge $=+2$ or +3 , MS error $=0.5 \mathrm{Da}, \mathrm{MS} / \mathrm{MS}$ error=0.5 Da. MS/MS spectra of one or more matched peptides with $\mathrm{p}<0.05$ were inspected visually; if the sequence was judged to be properly assigned to the spectrum, the protein was included in the list of released proteins.

\section{Results}

Cryogel monoliths

Purification of liver mitochondria yielded approx. 32 mg mitochondria pr gram tissue. Stimulation with 2 $\mu \mathrm{mol} \mathrm{CaCl} 2 / \mathrm{mg}$ mitochondria in suspension resulted in swelling of approx. $80 \%$ of the mitochondria, having set stimulation with 167 pmol alamethicin per mg mitochondria to $100 \%$ swelling. Mitochondria only interacted with monoliths with coupled Cu2+-IDA ligand; approximately $30 \%$ of the loaded mitochondria did not bind to the monoliths and were thus washed off in the first washes with CS-buffer. No detectable mitochondria were washed off after passage of 5 volumes of CS-buffer. Incubation in $10 \mathrm{mM}$ imidazole for up to one hour did not affect the swelling characteristics of mitochondria in suspension compared to control samples.

Scanning electron microscopy of monoliths showed that they had a continuous macroporous structure with a spongy morphology. Mitochondria had a round structure, and were bound to the monoliths in a nonorientable way, often in clusters in a "grape-like" structure. Upon visual inspection, no difference in the amount of bound mitochondria, or the grape-like structures, was seen between the three types (control, calcium, alamethicin) of treatments. Examination of an internal part of a monolith showed that slightly less mitochondria were bound half way down the monolith; all other characteristics remained the same indicating that the binding was uniform and that the binding capacity of the monoliths was not exceeded. Both SEM

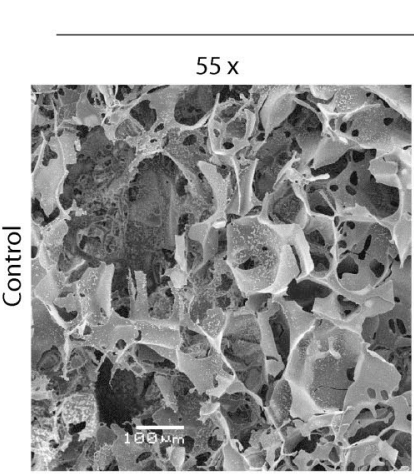

SEM
1100

SEM
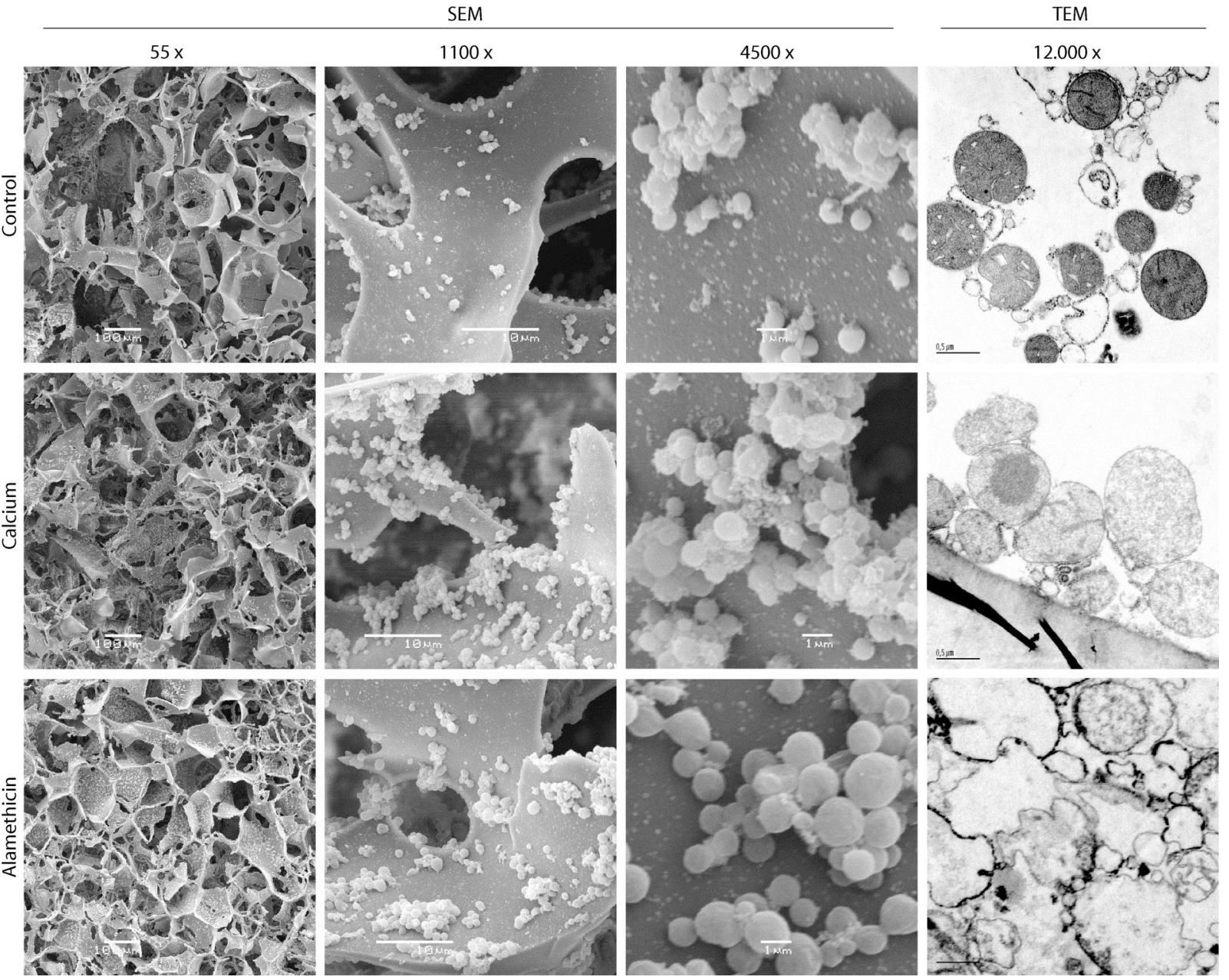

Figure 2. Electron microscopy. Scanning and transmission electron microscopy (SEM and TEM) of cryogel monoliths at increasing magnification: First row: untreated mitochondria, Second row: calcium-treated mitochondria, Third row: alamethicin treated mitochondria. At low magnification ( $55 \mathrm{X}$, first column) the porous structure of the cryogel monoliths is seen using SEM. Increasing the magnification (1100 X, second column) show that mitochondria bind to the surface in clusters. At high magnification (4500 X, third column) SEM show that the diameter of calcium and alamethicin treated mitochondria is increased compared to untreated mitochondria. TEM (12.000 X, fourth column) shows that the matrix of the treated mitochondria (calcium and alamethicin) is less dense than control mitocondria, i.e. mitochondria are swollen. These results are in line with a decreased ATP producing ability of the treated mitochondria. Scale bars indicate $100 \mu \mathrm{m}, 10 \mu \mathrm{m}, 1 \mu \mathrm{m}$, and $0.5 \mu \mathrm{m}$ for columns $1-4$, recnertively 
and TEM found the diameter of untreated mitochondria to be slightly less than $1 \mu \mathrm{m}$, approx. $1 \mu \mathrm{m}$ for calcium treated, and slightly above $1 \mu \mathrm{m}$ for alamethicin treated mitochondria (see figure 2), as visualised by electron micrographs at $4500 \mathrm{x}$ and 12.000 $\mathrm{x}$ magnification, respectively. Applying a very high dose of alamethicin resulted in complete disruption of the mitochondria; SEM showed mitochondria with large holes as well as small, resealed particles (data not shown). Transmission electron microscopy displayed a dense matrix of the untreated (control) mitochondria, and increasing swelling of the matrix in calcium or alamethicin treated mitochondria. $2 \mu \mathrm{mol} / \mathrm{mg}$ and 8 $\mu \mathrm{mol} / \mathrm{mg} \mathrm{CaCl} 2$ were tested on mitochondria bound on monoliths. SEM showed that $2 \mu \mathrm{mol} / \mathrm{mg}$ did not result in swelling of all mitochondria, and $8 \mu \mathrm{mol} / \mathrm{mg}$ was therefore used in the final protein-release experiments to better mimic the swelling in suspension.

Protein release from mitochondria bound to monoliths showed that there were no detectable proteins in the control samples $(<0.3 \mu \mathrm{g} / \mathrm{mg})$, approx. $16 \mu \mathrm{g} / \mathrm{mg}$ mitochondria for calcium treated, approx. $23 \mu \mathrm{g} / \mathrm{mg}$ for $\mathrm{Bid} / \mathrm{Bax}$, and approx. $70 \mu \mathrm{g} / \mathrm{mg}$ mitochondria for alamethicin treated samples. The released proteins were generally smaller than $100 \mathrm{kDa}$, with high abundances in the range from $20-50 \mathrm{kDa}$. Comparing several replicate experiments of calcium and $\mathrm{Bid} / \mathrm{Bax}$ released proteins, did not detect any consistent differences in the band profiles. Calcium stimulated protein release in suspension resulted in release of approx. $10 \mu \mathrm{g} / \mathrm{mg}$. The control samples in suspension released $50-75 \%$ of the amount released by calcium. PA gel electrophoresis confirmed this ratio, and showed that there was no consistent difference in the band profiles (see figure 3, suspension). The unspecific protein release did not decrease when the experiments were performed at room temperature (i.e. lower temperature). Different protocols for isolation of mitochondria were tested in an attempt to reduce the unspecific protein release, but it was never possible to reduce it to below $30 \%$ of that of calcium-induced samples (data not shown). The ATP production of mitochondria bound to monoliths was found to be somewhat higher than that of mitochondria in suspension $(27 \mathrm{nmol} / \mathrm{mg} / \mathrm{min}$ vs. $17 \mathrm{nmol} / \mathrm{mg} / \mathrm{min}$ respectively). Upon stimulation with calcium, the ATP production decreased to $38 \%$ on monoliths and to $21 \%$ in suspension, respectively. The applied dose of Bid and Bax did not change ATP production significantly. ATP production was only detected in samples with added ADP. Comparing the band profiles of several replicates of coomassie stained PA gels containing proteins released by calcium or Bid/Bax stimulation identified no differences, indicating that similar amounts of proteins of comparable sizes were released by the two

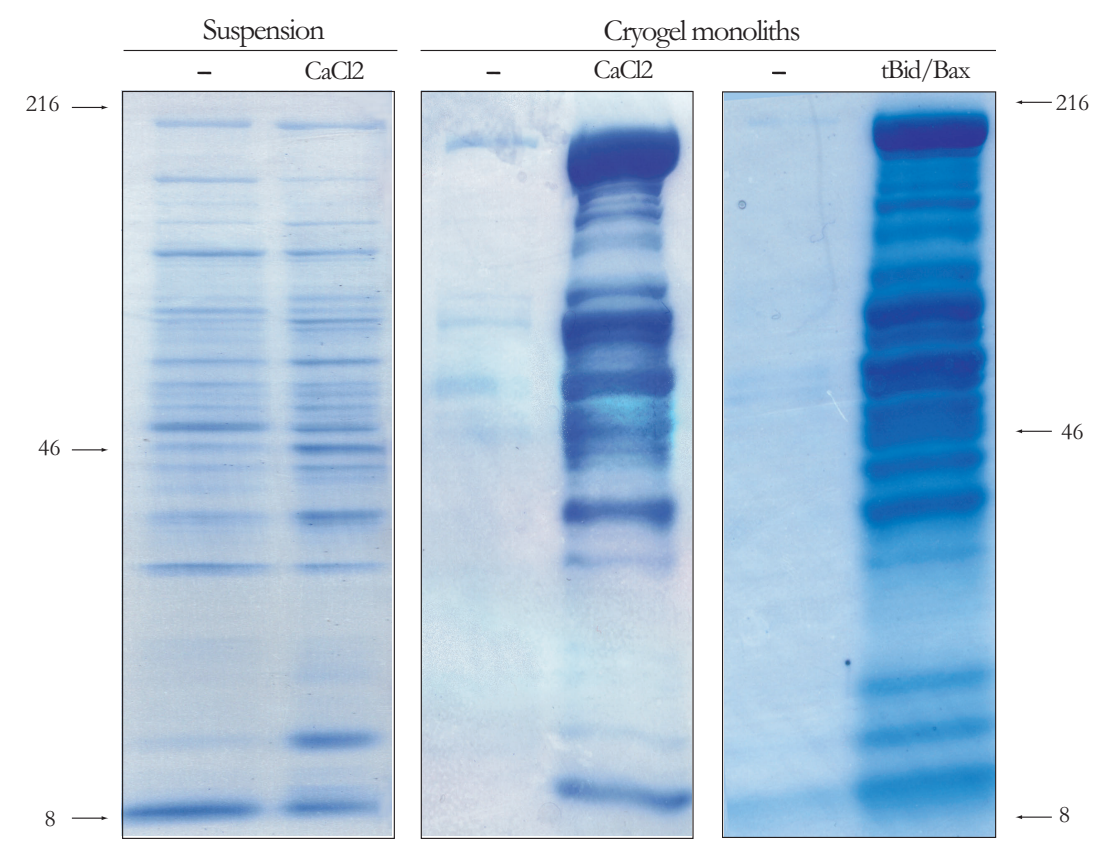

Figure 3. Polyacrylamide gels. Mitochondria in suspension or bound on monoliths were stimulated with 2 and $8 \mu \mathrm{mol} \mathrm{CaCl} / \mathrm{mg}$ mitochondria respectively, or $5.0 \mu \mathrm{g} / \mathrm{mL}$ Bid and Bax, and released proteins were collected and separated on polyacrylamide gels. The first two lanes contain proteins released from mitochondria in suspension (incubation and calcium); Lanes 3-6 contain proteins released from mitochondria bound to monoliths. Lane 3 and 5 contain incubation samples (-), whereas lane 4 and 6 contain proteins released by calcium or $\mathrm{Bid} / \mathrm{Bax}(+)$. Proteins released in suspension were separated on a $20 \mathrm{~cm}$ long $4-20 \%$ PA gel, whereas proteins released from bound mitochondria were separated on a $7 \mathrm{~cm}$ long 10-20\% PA gel. Horizontal arrows indicate size in $\mathrm{kDa}$. In suspension, the staining of the nonspecifically released proteins is almost as intense as that of proteins released upon calcium stimulation. When protein release is induced in mitochondria bound to monoliths, the nonspecifically released proteins can be washed away prior to analysis, and do thus not disturb the identification of the specifically released proteins (essentially no staining on PA gel). The proteins identified are thus specifically released upon $\mathrm{mPT}$ induction. In situ trypsin digestion, extraction and LC-MS/MS analysis on such samples (-/+ calcium in suspension) found no difference in the proteins present in the two situations. 
different stimuli.

\section{$L C-M S / M S$}

Pilot experiments showed that PA gel separation of 40 $\mu \mathrm{g}$ of proteins, released by calcium stimulation, resulted in identification of approx. 70 proteins. However, the control samples from suspension experiments contained a similar protein profile, albeit at lower concentration, meaning that it was not possible to identify proteins released as a result of the experimental manipulation. In the control samples from mitochondria bound to monoliths, it was not possible to detect, nor identify any released proteins (data not shown). These samples were therefore not included in the final LC-MS/MS analysis. For the two LC-MS/MS runs performed, complementary data were obtained. Based on results from the first run, the settings for the second run were optimized as described in materials and methods section. The adjustments resulted in better MS/MS data as well as better mass accuracy and resolution. Similarly, the increased threshold improved the quality of the data. The changed target mass resulted in a somewhat different set of selected peptides for MS/MS, thus complementing the first analysis. The quality of the MS/MS spectra was best in the second run, often allowing 5-7 consecutive ions to be assigned to peaks in the spectra with root mean square errors below 100 $\mathrm{ppm}$. The total ion composition trace showed that, as expected, the amount of sample present in the different gel pieces varied. Approx. $600 \mathrm{MS} / \mathrm{MS}$ spectra from each gelpiece were included in the database searches of both the web-accessible and the in-house Mascot search engines. In spite of the web-based Mascot search engine only allowing 300 spectra per search, we only found differences in the ions scores assigned (measure of the quality of the data), but no difference in the identified proteins when the result were compared to those obtained using the in-house version of Mascot. We did not attempt to calculate percent sequence coverage for searches performed with the in-house Mascot, but it might be higher than what we have displayed here (supplemental data, Table 1). Searching Swiss-Prot and National Center for Biotechnology Information (NCBI) databases also identified essentially the same proteins, when naming redundancies were eliminated. The results displayed in Table 1 are generated from searching the Swiss-Prot database using the web-based mascot search engine. As we found no differences between searches performed in NCBI and Swiss-Prot, we have displayed Swiss-Prot entry names and protein names, to avoid redundancies. From each gel slice, between 1 and 18 proteins were identified. A total of 68 unique proteins were identified in the calciumstimulated samples using the above stated criteria; 44 were identified in both LC-MS/MS runs, 9 were identified only in the first run, and the remaining 13 in the second run. These numbers include identifications made in only one sample. 41 of the proteins were identified in all three replicates from the different mitochondrial preparations. $81 \%$ of the proteins were identified by more than one peptide (see supplementary data, Figure 1, for a distribution of number of peptides per protein). For Bid/Bax released proteins, 82 proteins were identified in the single analysis performed; 45 of these were identical to proteins released by calcium. We did not attempt to look for specific proteins in the unassigned spectra. For a more extensive list of released proteins including their sizes, numbers of identified peptides and sequence coverage, see supplemental data, Table1. Obvious contaminants, such as keratin and trypsin, were not included in these lists. The contaminants yielded low ions scores, and most were only identified by a single peptide. According to ExPaCy's "subcellular localization" classification, 63\% of the calcium released proteins are localised to mitochondria, $12 \%$ in the cytosol, $6 \%$ are peroxisomal proteins, $3 \%$ are nuclear protein, and $4.5 \%$ are either secreted or ER proteins. For $12 \%$ of the proteins SwissProt does not provide information on the location of the protein. A similar distribution was seen for Bid/Bax released proteins.

\section{Discussion}

A few decades ago mitochondria were considered to be a power plant having only one purpose, namely to produce ATP for the cell. This is now known not to be the case; in addition to production of ATP, mitochondria actively participate in the intracellular signalling by releasing specific proteins upon a given stimulation, some of which participate in induction of cell death programs that are important for the propagation of cell death in e.g. neurodegenerative disease, myocardial infarction and liver ischemia. The mitochondrial permeability transition pore allows such release, as does stimulation with proapoptotic members of the Bcl-2 family of proteins, e.g. tBid and Bax.

Calcium is a central mediator of intracellular signals, and is involved both in physiological and pathophysiological cell signalling. Intracellular calcium levels may increase as a result of injury, e.g. excitotoxic injury caused by excessive release of glutamate in the brain. As calcium enters the cell, it is sequestered in mitochondria as a consequence of the mitochondrial membrane potential, and may there induce $\mathrm{mPT}$. The dynamics of calciuminduced stimulation of $\mathrm{mPT}$ is complex, and it has been suggested that in vivo, mitochondria may release proteins as intracellular calcium levels increase e.g. as a result of injury $[6,7]$. As the tissue recovers, calcium may be extruded from the cell, and the mPTP reverts to the closed state. Released proteins (e.g. cytochrome c) may then be taken up again by the mitochondria, and the initiation of cell death programs cancelled. Pharmacological inhibition of the $\mathrm{mPT}$ and the associated release of cell death-inducing proteins have been shown to have a very potent cytoprotective effect in several settings [45], and so has counteracting the 


\begin{tabular}{|c|c|c|c|}
\hline $\begin{array}{l}\text { SwissProt entry } \\
\text { name }\end{array}$ & Protein name & $\begin{array}{l}\text { SwissProt entry } \\
\text { name }\end{array}$ & Protein name \\
\hline CH10_RAT & $10 \mathrm{kDa}$ heat shock protein & DHE4_PANTR & Glutamate dehydrogenase 2 \\
\hline D3D2_RAT & 3,2-trans-enoyl-CoA isomerase & KAD3_RAT & GTP:AMP phosphotransferase \\
\hline HCD2_RAT & 3-hydroxyacyl-CoA dehydrogenase type II & HMCS2_RAT & Hydroxymethylglutaryl-CoA synthase \\
\hline 3HIDH_RAT & 3-hydroxyisobutyrate dehydrogenase & IDHP_MOUSE & Isocitrate dehydrogenase [NADP] \\
\hline THIM_RAT & 3-ketoacyl-CoA thiolase & IVD_RAT & Isovaleryl-CoA dehydrogenase \\
\hline THTM_RAT & 3-mercaptopyruvate sulfurtransferase & MUP_RAT & Major urinary protein \\
\hline CH60_RAT & $60 \mathrm{kDa}$ heat shock protein & MDHM_RAT & Malate dehydrogenase \\
\hline THIL_RAT & Acetyl-CoA acetyltransferase & MAAI_MOUSE & Maleylacetoacetate isomerase \\
\hline ACON_RAT & Aconitate hydratase & MMSA_RAT & $\begin{array}{l}\text { Methylmalonate-semialdehyde dehydrogenase } \\
\text { [acylating] }\end{array}$ \\
\hline ACADL_RAT & Acyl-CoA dehydrogenase, long-chain specific & NEUL_RAT & Neurolysin \\
\hline ACADM_RAT & Acyl-CoA dehydrogenase, medium-chain specific & NDKB_RAT & Nucleoside diphosphate kinase B \\
\hline ACADS_RAT & Acyl-CoA dehydrogenase, short-chain specific & OTC_RAT & Ornithine carbamoyltransferase \\
\hline KAD4_RAT & Adenylate kinase isoenzyme 4 & BPT1_BOVIN & Pancreatic trypsin inhibitor \\
\hline AL4A1_MOUSE & Aldehyde dehydrogenase $4 \mathrm{~A} 1$ & PPIB_RAT & Peptidyl-prolyl cis-trans isomerase B \\
\hline AL7A1_HUMAN & Aldehyde dehydrogenase family 7 member $A 1$ & PPIF_RAT & Peptidyl-prolyl cis-trans isomerase F \\
\hline ALDH2_RAT & Aldehyde dehydrogenase, mitochondrial & PIN4_MOUSE & $\begin{array}{l}\text { Peptidyl-prolyl cis-trans isomerase NIMA- } \\
\text { interacting } 4\end{array}$ \\
\hline AMACR_RAT & Alpha-methylacyl-CoA racemase & PRDX1_RAT & Peroxiredoxin 1 \\
\hline AATM_RAT & Aspartate aminotransferase & PRDX5_RAT & Peroxiredoxin 5 \\
\hline C1TC_RAT & C-1-tetrahydrofolate synthase & ECHP_RAT & Peroxisomal bifunctional enzyme \\
\hline CPSM_RAT & Carbamoyl-phosphate synthase & DHB4_RAT & Peroxisomal multifunctional enzyme type 2 \\
\hline CAH2_BOVIN & Carbonic anhydrase II & PA2G4_MOUSE & Proliferation-associated protein 2G4 \\
\hline CATA_MOUSE & Catalase & PYC_RAT & Pyruvate carboxylase \\
\hline CYC_RAT & Cytochrome c & UK14_RAT & Ribonuclease UK114 \\
\hline COX17_MOUSE & Cytochrome $\mathrm{c}$ oxidase copper chaperone & RRBP1_RAT & Ribosome-binding protein 1 \\
\hline DHRS4_RAT & Dehydrogenase/reductase SDR family member 4 & SARDH_RAT & Sarcosine dehydrogenase \\
\hline M2GD_RAT & Dimethylglycine dehydrogenase & ALBU_RAT & Serum albumin \\
\hline ETFA_RAT & Electron transfer flavoprotein alpha-subunit & HCDH_RAT & Short chain 3-hydroxyacyl-CoA dehydrogenase \\
\hline ETFB_MOUSE & Electron transfer flavoprotein beta-subunit & SERF2_MOUSE & Small EDRK-rich factor 2 \\
\hline EF11_RAT & Elongation factor 1 -alpha 1 & SND1_RAT & $\begin{array}{l}\text { Staphylococcal nuclease domain containing } \\
\text { protein } 1\end{array}$ \\
\hline ECHM_RAT & Enoyl-CoA hydratase & GRP75_RAT & Stress-70 protein \\
\hline ES1_MOUSE & ES1 protein homolog & SODC_RAT & Superoxide dismutase [Cu-Zn] \\
\hline FKBP3_MOUSE & FK506-binding protein 3 & SODM_RAT & Superoxide dismutase [Mn] \\
\hline ALDOB_RAT & Fructose-bisphosphate aldolase B & THTR_RAT & Thiosulfate sulfurtransferase \\
\hline DHE3_RAT & Glutamate dehydrogenase 1 & BPHL_MOUSE & Valacyclovir hydrolase \\
\hline
\end{tabular}

Table 1 Released proteins. Specifically released proteins from calcium stimulated liver mitochondria. Swiss-Prot entry name and protein name is listed for the 68 proteins identified in the two LC-MS/MS analysis'. Proteins identified from peptides with $95 \%$ confidence in one sample are included in the list. $81 \%$ of the proteins were identified by two or more peptides. Obvious contaminants (e.g. keratin and trypsin) were not included. For a more detailed list, including identification in the three replicates, see supplementary data.

proapoptotic effects of Bax by e.g. over expression of $\mathrm{Bcl}-2$ [46]. As mentioned in the introduction, it is currently not clear if the $\mathrm{mPT}$ and Bax mediated pathways converge in mitochondria and share a common downstream pathway in the induction of cell death. Therefore, the mechanisms underlying activation of $\mathrm{mPT}$ and Bax-mediated cell death, as well as the identity of the released factors have been the focus of intense research over the last decade. Several approaches for studying protein release from mitochondria have been published [15, 26-28]; all of these studies have brought about interesting information about proteins released from mitochondria. They used centrifugation/resuspension to isolate mitochondria and suspensions to collect the proteins released following stimulation, and although data from the control samples are not presented in all studies, they all indicate that there was a high degree of unspecific release (background), which in line with our findings. This unspecific release is probably caused by mitochondria bursting as a result of the (unphysiological) forces caused by repeated centrifugation and resuspension. This paper is the first to indicate a solution to the problem of unspecific protein release, and presents a tool that can be used to delineate the effects of different stimuli leading to mitochondria-mediated cell death. We show that by binding mitochondria to monoliths, it is possible to wash nonspecifically released proteins away prior to performing the actual experiments. This allows the isolation of the specifically released proteins, and hence a 
more detailed insight into which proteins are released as a result of the experimental manipulation, rather than by centrifugation and resuspension of the mitochondria.

Monoliths have previously been used to separate, isolate or fractionate cells, viruses and recombinant proteins. By changing the binding surface of the monoliths it is possible to apply them in almost any situation where separation is needed. Water or buffer inside the pores of the monoliths constitutes nearly $90 \%$ of their weight $[32,47]$. The environment is thus very similar to the commonly used in vitro system for studying mitochondria, i.e. suspension. Due to capillary forces, the liquid is kept inside the pores and can be displaced from the monolith by addition of a new portion of liquid. This makes the monoliths ideal for binding and studying mitochondria. Scanning- and transmission electron microscopy showed that upon calcium stimulation, mitochondria display the same morphology as previously reported for mitochondria in suspension following calcium stimulation [9]. When bound to monoliths, mitochondria cluster together in "grape-like" structures independent of their treatment. Clustering has also been reported from atomic force surface scans of mitochondria in vitro [48] and might thus be an intrinsic feature of mitochondria in vitro. The ATP production was found to be intact in control samples of mitochondria bound to the monoliths, indicating that the mitochondria were viable after binding to the monoliths. The ATP production was disrupted following addition of calcium, both in suspension and in samples bound to the monoliths, suggesting a similar functional response to a calcium challenge. Furthermore, the diameter of monolith-attached mitochondria was similar to that of mitochondria in suspension, both in control samples and following a calcium challenge. The characteristics of mitochondria bound to monoliths are thus apparently identical to those of mitochondria in suspension.

The binding of the mitochondria to the monoliths is quite robust; once the mitochondria are bound, they are not released by several passages of buffer, or by addition of permeabilising agents. Incubation of up to $60 \mathrm{~min}$ does not induce spontaneous rupture or unspecific protein release yielding a blank incubation sample. The calcium dose necessary to elicit swelling of a large portion of mitochondria bound to monoliths is four times higher than the dose needed for a similar degree of mitochondrial swelling in suspension. This could be caused by restricted diffusion within the monoliths; as mitochondria are immobilised, the probability of encountering a calcium-ion are lower than if they were moving freely. A similar phenomenon is seen for agonist-binding studies on monoliths (M. Dainiak, unpublished studies). The ATP production was found to be intact for the applied Bid and Bax dose, which is consistent with the suggested role of $\mathrm{Bid} / \mathrm{Bax}$ in permeabilization of only the outer mitochondrial membrane. Taking the above-mentioned concentration-effects into consideration, further studies on the microscopic morphology of the mitochondria treated with $\mathrm{Bid} / \mathrm{Bax}$ should be performed to firmly establish the consequences of the applied dose in the monolith system.

For the identification of the released proteins, a proteomics method, which combines PA gel electrophoresis, liquid chromatography and tandem mass spectrometry, was applied. The method is simple and easily performed by researchers with limited experience on PA gels and LC-MS/MS [31]. The method allows detection of individual proteins in a complex solution of proteins, with a sensitivity of 10 fmol, and circumvents the problem of resolving mitochondrial proteins, which often have extreme $\mathrm{pI}$ $[30,31]$, on 2D gels. The technique is performed most elegantly on a HPLC coupled directly to a mass spectrometer, but can also be performed off-line. By separating the proteins according to size, using PA gel electrophoresis, prior to LC-MS/MS analysis, only peptides from a limited number of proteins will be present in each sample. This allows the threshold for the analysis to be set low, and for the MS/MS runs to take up more time as fewer peptides elute simultaneously. Hereby efficient identification of many peptides is allowed, which results in good sequence coverage of the identified proteins, and in identification of low abundant proteins. For the current set-up $81 \%$ of the identified proteins were identified by two or more peptides (See supplemental figure 1). Should the sample contain too many proteins, the lower abundant proteins will be disguised by the high abundant proteins, and thus not included in the MS/MS analysis. By simply dividing the PA gel in smaller slices, it is possible to reduce the complexity of the protein mixture, thereby increasing sensitivity to low abundant proteins. Methods such as affinity-purifying peptides containing cysteinyl residues [29] prior to analysis by LC-MS/MS can also be used to simplify protein mixtures, but include more laborious steps and probably increased loss of low-abundance peptides compared to the technique applied in this study. The applied LC-MS/MS method does not allow quantitative comparisons to be performed, but as the unspecific release (background) has been eliminated, this is not required.

We found that the band profile of both calcium and $\mathrm{Bid} / \mathrm{Bax}$ released proteins were reproducible and similar to each other. A comparison of the proteins identified by LC-MS/MS showed that a majority of the proteins were found in both the calcium samples and the $\mathrm{Bid} / \mathrm{Bax}$ sample. The same degree of inter-sample variation, found for the three calcium samples, was seen between the calcium and the Bid/Bax sample. For the proteins unique to either permeabilising agent, there was no difference in the studied characteristics, such as size and localisation, indicating that the end effect of calcium and $\mathrm{Bid} / \mathrm{Bax}$ stimulation is release of highly similar proteins. Our results indicate nothing on the 
similarities in the mechanism of release, but indicate that with the applied concentrations of $\mathrm{Bid} / \mathrm{Bax}$, the end result is release of proteins from both the intermembrane space, and the matrix for both calcium and Bid/Bax. A study somewhat similar to ours was performed by Patterson et al [26] using atractyloside to open the MPTP, and LC-LC/MS-MS to detect released proteins. Atractyloside is a ligand for the ANT component of the pore, increasing the open-probability of the pore [3] by stabilising the "c conformation" of ANT thereby increasing its sensitivity to calcium, and resulting in opening of $\mathrm{mPTP}$. As atractyloside binds non-reversibly to ANT, the pore opening cannot be reversed as opposed to calcium induced $\mathrm{mPTP}$. Patterson et al [26] identified 34 of the 68 proteins we identified, as well as 57 proteins not seen in our analysis. We on the other hand detected 34 proteins, which were not detected upon atractyloside treatment. When comparing the characteristics of the proteins released by atractyloside treatment [26], we find that the two techniques display proteins of essentially the same size, and that there is no apparent difference in the nature or function of the identified proteins. The cellular localization of the identified proteins is also similar in the two studies. The fact that our results from samples, where the background has been eliminated, so closely resembles those of Patterson et al suggests that the release mechanism following $\mathrm{mPT}$-induction using calcium and atractyloside are similar, and that the release of proteins occur in an unspecific way, likely due to osmotic swelling and rupture of the outer mitochondrial membrane. Importantly, this conclusion was not possible until the non-specific release was eliminated. Van Loo [27] used tBID to stimulate protein release from mitochondria. They applied technique similar to ours for detection (PA gel electrophoresis followed by LC and MALDI analysis for relevant bands), but as the unspecific release was almost similar to the tBIDstimulated release, they were only able to detect 7 of the 68 and 83 proteins we detected in our analyses. They identified a further 9 proteins, several of which are low abundant, thus explaining our lack of identification using the less sensitive MS/MS technique.

The presented list of proteins includes some of the proteins known to be released from mitochondria, such as Cytochrome c and Hsp10. It however lacks some candidates previously described to be released during mitochondria mediated cell death. Proteins such as Smac/DIABLO, EndoG, Omi/HtrA2 and AIF have all been described to be released from mitochondria following induction of $\mathrm{mPT}$ or by Bax-stimulation. Although some of these proteins require specific conditions, e.g. concomitant activation of Calpains to be released [49] and thus may not be released in our model, the most likely explanation for their absence is their low abundance, as was also indicated by Patterson et al [26]. For example, AIF constitute less than $0.1 \%$ of mitochondrial proteins [50], and is thus close to the detection limit of this technique. To enhance detection of low abundance proteins, the LC-MS/MS analysis can be re-run with preference to peptides not identified in the regular run, with preference to peptides from proteins of interest, or the PA gel can be further divided in smaller sections to reduce the number of proteins in each sample. Other techniques for protein identification with greater sensitivity, such as MALDITOF-TOF, could also be applied. This was not attempted in the current analysis.

For a number of reasons, it is difficult to study mitochondrial function in situ, and mitochondrial experiments in vitro is at present the experimental system that best allows experimental manipulation and evaluation of mitochondrial response. However, the in vitro system means that mitochondria are removed from the intracellular environment, and subjected to repeated centrifugations etc. Using the method presented here, mitochondria could be subjected to experimental manipulations closer to those in situ, without being subjected to repeated centrifugations. One example would be a transient calcium challenge, where administered calcium is washed away after a suitable time, and the mPTP allowed to revert to the closed state [9]. Further, the monoliths could be coated with intracellular proteins of interest, e.g. cytoskeleton proteins to allow for mitochondrial interaction with other cellular constituents in the experimental setting.

The present paper thus presents a new method for studying protein release from isolated mitochondria. The method circumvents the obstacle of protein leakage from mitochondria, and looks at proteins specifically released from mitochondria as a result of cell deathinducing signals. We demonstrate that mitochondria bound to monoliths retain their usual characteristics, such as ATP generation and swelling. By combining separation of proteins based on size with LC-MS/MS, we identified 68 proteins specifically released upon calcium stimulation of liver mitochondria. We furthermore show that the profile of proteins released by calcium and Bid/Bax are similar, indicating that the end results of these two treatment types are identical. To comprehend the complex biology of protein release from mitochondria detailed studies need to be performed; we have now introduced a tool, which will allow these studies to be performed, and encourage the scientific community to take up this challenge.

\section{Acknowledgments}

Bo Mattiasson and Igor Galaev are thanked for invaluable ideas and inputs for setting up the monolith system for mitochondria. Rita Wallen is thanked for expertly performing the electron microscopy. The Lundbeck Foundation, Danielsens Foundation, and Dagmar Marshalls Foundation are thanked for financial support of M. Teilum. The Wiberg, Crafoord, Laerdal, Marta Larsson, G\&J Kock, Thuring, Bergvall and Swedish Brain Foundations, The Swedish STROKE 
Association, The Royal Physiographic Society, The Swedish Society for Medicine and The Swedish Research Council (Project No. 08644) are thanked for financial support of G. Mattiasson and E. Elmér.

\section{Supplementary data}

Supplementary data associated with this article can be found at the end of this paper.

\section{References}

1. Mattson, M. P., and Kroemer, G. Mitochondria in cell death: novel targets for neuroprotection and cardioprotection, Trends Mol Med 9 (2003) 196-205.

2. Green, D. R., and Kroemer, G. The pathophysiology of mitochondrial cell death, Science 305 (2004) 626-9.

3. Halestrap, A. P., McStay, G. P., and Clarke, S. J. The permeability transition pore complex: another view, Biochimie 84 (2002) 153-66.

4. Crompton, M., Costi, A., and Hayat, L. Evidence for the presence of a reversible $\mathrm{Ca} 2+-$ dependent pore activated by oxidative stress in heart mitochondria, Biochem J 245 (1987) 915-8.

5. Crompton, M. The mitochondrial permeability transition pore and its role in cell death, Biochem J 341 ( Pt 2) (1999) 233-49.

6. Ferrand-Drake, M., Friberg, H., and Wieloch, T. Mitochondrial permeability transition induced DNAfragmentation in the rat hippocampus following hypoglycemia, Neuroscience 90 (1999) 1325-38.

7. Morin, D., Pires, F., Plin, C., and Tillement, J. P. Role of the permeability transition pore in cytochrome $\mathrm{C}$ release from mitochondria during ischemia-reperfusion in rat liver, Biochem Pharmacol 68 (2004) 2065-73.

8. Friberg, H., Connern, C., Halestrap, A. P., and Wieloch, T. Differences in the activation of the mitochondrial permeability transition among brain regions in the rat correlate with selective vulnerability, J Neurochem 72 (1999) 2488-97.

9. Hansson, M. J., Månsson, R., Mattiasson, G., Ohlsson, J., Karlsson, J., Keep, M. F., and Elmer, E. Brain-derived respiring mitochondria exhibit homogeneous, complete and cyclosporin-sensitive permeability transition, J Neurochem 89 (2004) 715-29.

10. Hansson, M. J., Persson, T., Friberg, H., Keep, M. F., Rees, A., Wieloch, T., and Elmer, E. Powerful cyclosporin inhibition of calcium-induced permeability transition in brain mitochondria, Brain Res 960 (2003) 99-111.

11. Bernardi, P. Mitochondrial transport of cations: channels, exchangers, and permeability transition, Physiol Rev 79 (1999) 1127-55.

12. Hansson, M. J., Mattiasson, G., Månsson, R., Karlsson, J., Keep, M. F., Waldmeier, P., Ruegg, U. T., Dumont, J. M., Besseghir, K., and Elmer, E. The Nonimmunosuppressive Cyclosporin Analogs NIM811 and UNIL025 Display Nanomolar Potencies on Permeability Transition in BrainDerived Mitochondria, J Bioenerg Biomembr 36 (2004) 407 13.

13. Baines, C. P., Kaiser, R. A., Purcell, N. H., Blair, N. S., Osinska, H., Hambleton, M. A., Brunskill, E. W., Sayen, M. R., Gottlieb, R. A., Dorn, G. W., Robbins, J., and Molkentin, J. D. Loss of cyclophilin D reveals a critical role for mitochondrial permeability transition in cell death, Nature 434 (2005) 658-62.

14. Nakagawa, T., Shimizu, S., Watanabe, T., Yamaguchi, O., Otsu, K., Yamagata, H., Inohara, H., Kubo, T., and Tsujimoto, Y. Cyclophilin D-dependent mitochondrial permeability transition regulates some necrotic but not apoptotic cell death, Nature 434 (2005) 652-658.
15. Kuwana, T., Mackey, M. R., Perkins, G., Ellisman, M. H., Latterich, M., Schneiter, R., Green, D. R., and Newmeyer, D. D. Bid, Bax, and lipids cooperate to form supramolecular openings in the outer mitochondrial membrane, Cell 111 (2002) 331-42.

16. Desagher, S., and Martinou, J. C. Mitochondria as the central control point of apoptosis, Trends Cell Biol 10 (2000) 36977.

17. Wennersten, A., Holmin, S., and Mathiesen, T. Characterization of $\mathrm{Bax}$ and $\mathrm{Bcl}-2$ in apoptosis after experimental traumatic brain injury in the rat, Acta Neuropathol (Berl) 105 (2003) 281-8.

18. Gross, A., Jockel, J., Wei, M. C., and Korsmeyer, S. J. Enforced dimerization of BAX results in its translocation, mitochondrial dysfunction and apoptosis, Embo J 17 (1998) 3878-85.

19. Hsu, Y. T., Wolter, K. G., and Youle, R. J. Cytosol-tomembrane redistribution of $\mathrm{Bax}$ and $\mathrm{Bcl}-\mathrm{X}(\mathrm{L})$ during apoptosis, Proc Natl Acad Sci U S A 94 (1997) 3668-72.

20. Wolter, K. G., Hsu, Y. T., Smith, C. L., Nechushtan, A., Xi, X. G., and Youle, R. J. Movement of Bax from the cytosol to mitochondria during apoptosis, J Cell Biol 139 (1997) 128192.

21. Eskes, R., Antonsson, B., Osen-Sand, A., Montessuit, S., Richter, C., Sadoul, R., Mazzei, G., Nichols, A., and Martinou, J. C. Bax-induced cytochrome C release from mitochondria is independent of the permeability transition pore but highly dependent on $\mathrm{Mg} 2+$ ions, J Cell Biol 143 (1998) 217-24.

22. Jurgensmeier, J. M., Xie, Z., Deveraux, Q., Ellerby, L., Bredesen, D., and Reed, J. C. Bax directly induces release of cytochrome c from isolated mitochondria, Proc Natl Acad Sci U S A 95 (1998) 4997-5002.

23. Desagher, S., Osen-Sand, A., Nichols, A., Eskes, R., Montessuit, S., Lauper, S., Maundrell, K., Antonsson, B., and Martinou, J. C. Bid-induced conformational change of Bax is responsible for mitochondrial cytochrome c release during apoptosis, J Cell Biol 144 (1999) 891-901.

24. Eskes, R., Desagher, S., Antonsson, B., and Martinou, J. C. Bid induces the oligomerization and insertion of Bax into the outer mitochondrial membrane, Mol Cell Biol 20 (2000) 929-35.

25. Wei, M. C., Lindsten, T., Mootha, V. K., Weiler, S., Gross, A., Ashiya, M., Thompson, C. B., and Korsmeyer, S. J. tBID, a membrane-targeted death ligand, oligomerizes BAK to release cytochrome c, Genes Dev 14 (2000) 2060-71.

26. Patterson, S. D., Spahr, C. S., Daugas, E., Susin, S. A., Irinopoulou, T., Koehler, C., and Kroemer, G. Mass spectrometric identification of proteins released from mitochondria undergoing permeability transition, Cell Death Differ 7 (2000) 137-44.

27. Van Loo, G., Demol, H., van Gurp, M., Hoorelbeke, B., Schotte, P., Beyaert, R., Zhivotovsky, B., Gevaert, K., Declercq, W., Vandekerckhove, J., and Vandenabeele, P. A matrix-assisted laser desorption ionization post-source decay (MALDI-PSD) analysis of proteins released from isolated liver mitochondria treated with recombinant truncated Bid, Cell Death Differ 9 (2002) 301-8.

28. Lovell, M. A., Xiong, S., Markesbery, W. R., and Lynn, B. C. Quantitative proteomic analysis of mitochondria from primary neuron cultures treated with amyloid beta peptide, Neurochem Res 30 (2005) 113-22.

29. Spahr, C. S., Susin, S. A., Bures, E. J., Robinson, J. H., Davis, M. T., McGinley, M. D., Kroemer, G., and Patterson, S. D. Simplification of complex peptide mixtures for proteomic analysis: reversible biotinylation of cysteinyl peptides, Electrophoresis 21 (2000) 1635-50.

30. Mootha, V. K., Bunkenborg, J., Olsen, J. V., Hjerrild, M., Wisniewski, J. R., Stahl, E., Bolouri, M. S., Ray, H. N., 
Sihag, S., Kamal, M., Patterson, N., Lander, E. S., and Mann, M. Integrated analysis of protein composition, tissue diversity, and gene regulation in mouse mitochondria, Cell 115 (2003) 629-40.

31. Rezaul, K., Wu, L., Mayya, V., Hwang, S. I., and Han, D. A systematic characterization of mitochondrial proteome from human T leukemia cells, Mol Cell Proteomics 4 (2005) 16981.

32. Lozinsky, V. I., Plieva, F. M., Galaev, I. Y., and Mattiasson, B. The potential of polymeric cryogels in bioseparation, Bioseparation 10 (2001) 163-88.

33. Arvidsson, P., Plieva, F. M., Savina, I. N., Lozinsky, V. I., Fexby, S., Bulow, L., Galaev, I. Y., and Mattiasson, B. Chromatography of microbial cells using continuous supermacroporous affinity and ion-exchange columns, J Chromatogr A 977 (2002) 27-38.

34. Kumar, A., Plieva, F. M., Galaev, I. Y., and Mattiasson, B. Affinity fractionation of lymphocytes using a monolithic cryogel, J Immunol Methods 283 (2003) 185-94.

35. Dainiak, M. B., Plieva, F. M., Galaev, I. Y., Hatti-Kaul, R., and Mattiasson, B. Cell Chromatography: Separation of Different Microbial Cells Using IMAC Supermacroporous Monolithic Columns, Biotechnol Prog 21 (2005) 644-9.

36. Williams, S. L., Eccleston, M. E., and Slater, N. K. Affinity capture of a biotinylated retrovirus on macroporous monolithic adsorbents: towards a rapid single-step purification process, Biotechnol Bioeng 89 (2005) 783-7.

37. Arvidsson, P., Plieva, F. M., Lozinsky, V. I., Galaev, I. Y., and Mattiasson, B. Direct chromatographic capture of enzyme from crude homogenate using immobilized metal affinity chromatography on a continuous supermacroporous adsorbent, J Chromatogr A 986 (2003) 275-90.

38. Dainiak, M. B., Kumar, A., Plieva, F. M., Galaev, I. Y., and Mattiasson, B. Integrated isolation of antibody fragments from microbial cell culture fluids using supermacroporous cryogels, J Chromatogr A 1045 (2004) 93-8.

39. Priault, M., Cartron, P. F., Camougrand, N., Antonsson, B. Vallette, F. M., and Manon, S. Investigation of the role of the C-terminus of Bax and of tc-Bid on Bax interaction with yeast mitochondria, Cell Death Differ 10 (2003) 1068-77.

40. Halestrap, A. P., Quinlan, P. T., Whipps, D. E., and Armston, A. E. Regulation of the mitochondrial matrix volume in vivo and in vitro. The role of calcium, Biochem J 236
(1986) 779-87.

41. Bradford, M. M. A rapid and sensitive method for the quantitation of microgram quantities of protein utilizing the principle of protein-dye binding, Anal Biochem 72 (1976) 248-54.

42. Hunter, D. R., and Haworth, R. A. The Ca2+-induced membrane transition in mitochondria. I. The protective mechanisms, Arch Biochem Biophys 195 (1979) 453-9.

43. Hirsch, T., Dallaporta, B., Zamzami, N., Susin, S. A., Ravagnan, L., Marzo, I., Brenner, C., and Kroemer, G. Proteasome activation occurs at an early, premitochondrial step of thymocyte apoptosis, J Immunol 161 (1998) 35-40.

44. Rappsilber, J., Ishihama, Y., and Mann, M. Stop and go extraction tips for matrix-assisted laser desorption/ionization, nanoelectrospray, and LC/MS sample pretreatment in proteomics, Anal Chem 75 (2003) 663-70.

45. Waldmeier, P. C., Zimmermann, K., Qian, T., TintelnotBlomley, M., and Lemasters, J. J. Cyclophilin D as a drug target, Curr Med Chem 10 (2003) 1485-506.

46. Saikumar, P., Dong, Z., Patel, Y., Hall, K., Hopfer, U., Weinberg, J. M., and Venkatachalam, M. A. Role of hypoxiainduced Bax translocation and cytochrome $\mathrm{c}$ release in reoxygenation injury, Oncogene 17 (1998) 3401-15.

47. Plieva, F. M., Andersson, J., Galaev, I. Y., and Mattiasson, B. Characterization of polyacrylamide based monolithic columns, J Sep Sci 27 (2004) 828-36.

48. Layton, B. E., Sastry, A. M., Lastoskie, C. M., Philbert, M. A., Miller, T. J., Sullivan, K. A., Feldman, E. L., and Wang, C. W. In situ imaging of mitochondrial outer-membrane pores using atomic force microscopy, Biotechniques 37 (2004) 564-70, 572-3.

49. Polster, B. M., Basanez, G., Etxebarria, A., Hardwick, J. M., and Nicholls, D. G. Calpain I induces cleavage and release of apoptosis-inducing factor from isolated mitochondria, J Biol Chem 280 (2005) 6447-54.

50. Susin, S. A., Zamzami, N., Castedo, M., Hirsch, T., Marchetti, P., Macho, A., Daugas, E., Geuskens, M., and Kroemer, G. Bcl-2 inhibits the mitochondrial release of an apoptogenic protease, J Exp Med 184 (1996) 1331-41. 


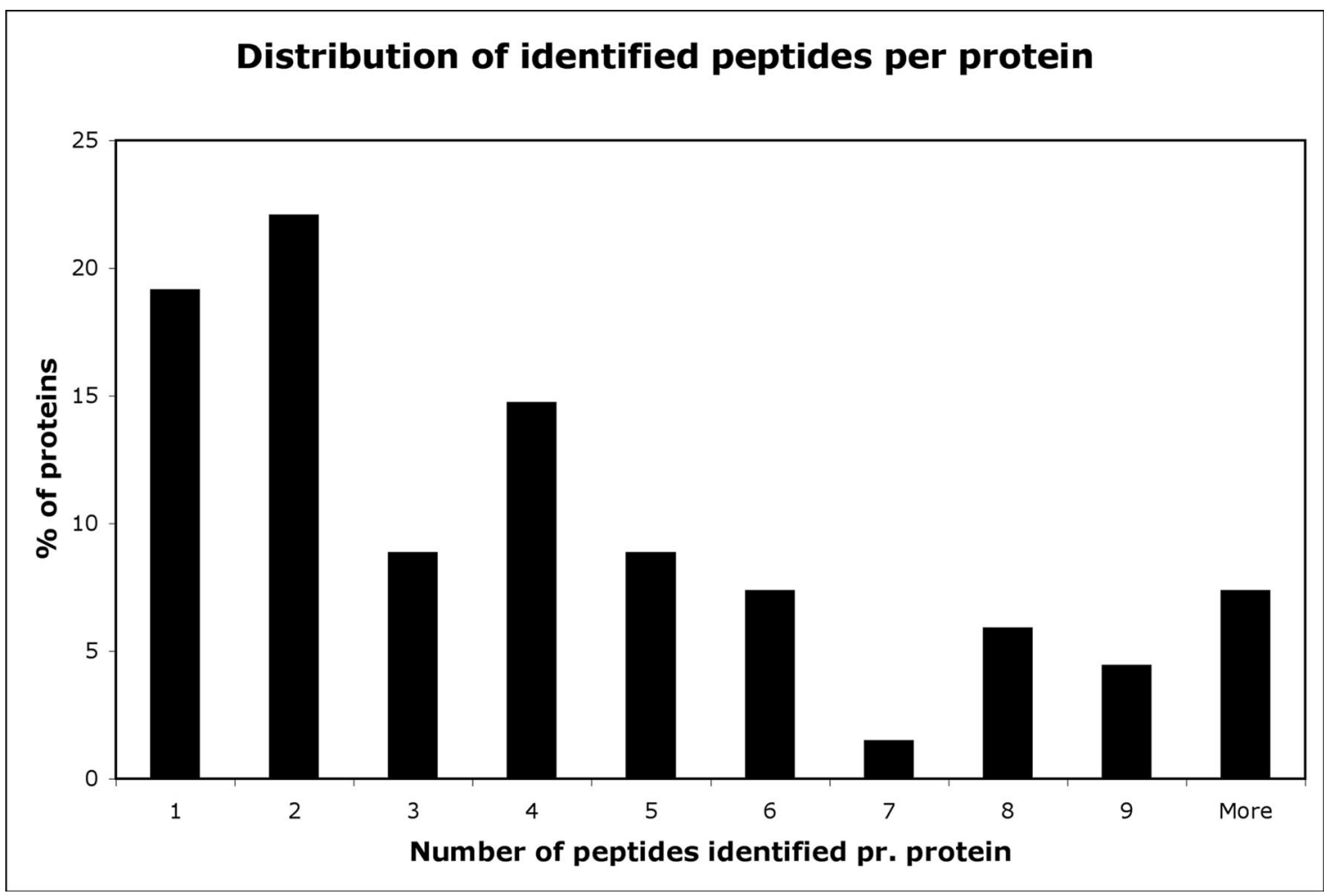

Figure 1, suppl. Identified peptides per protein. Number of identified peptides per protein shows that with the applied combination of PA gel electrophoresis and LC-MS/MS, it is often possible to identify several peptides per protein. More than half of the proteins were identified by three or more peptides. Proteins, only identified by one peptide are included in the list of released proteins if the ions score indicate that the match is not random $(-10 \log (P)$, where $P$ is the probability that the observed match is a random event). As the obtained MS/MS data yields high ions scores, and the spectra are of good quality, we find this acceptable, although the risk of false assignments is higher for this group of proteins.

Table 1 suppl. Details for released proteins. Core data (sequence and taxonomy) and annotations according to Swiss-Prot database, for the 68 proteins released upon calcium stimulation. Acc.no: accession number, Localization: localization according to Swiss-Prot (if localization is not available from Swiss-Prot, field is left blank). MS/MS analysis: 1st MS/MS analysis (enhanced mode) or 2nd MS/MS analysis (ultrascan mode). Sample 1-3: three replicates made from separate mitochondrial preparations. Number of peptides: number of peptides identified for annotated protein. Sequence coverage: percent of sequence covered by identified peptides. 


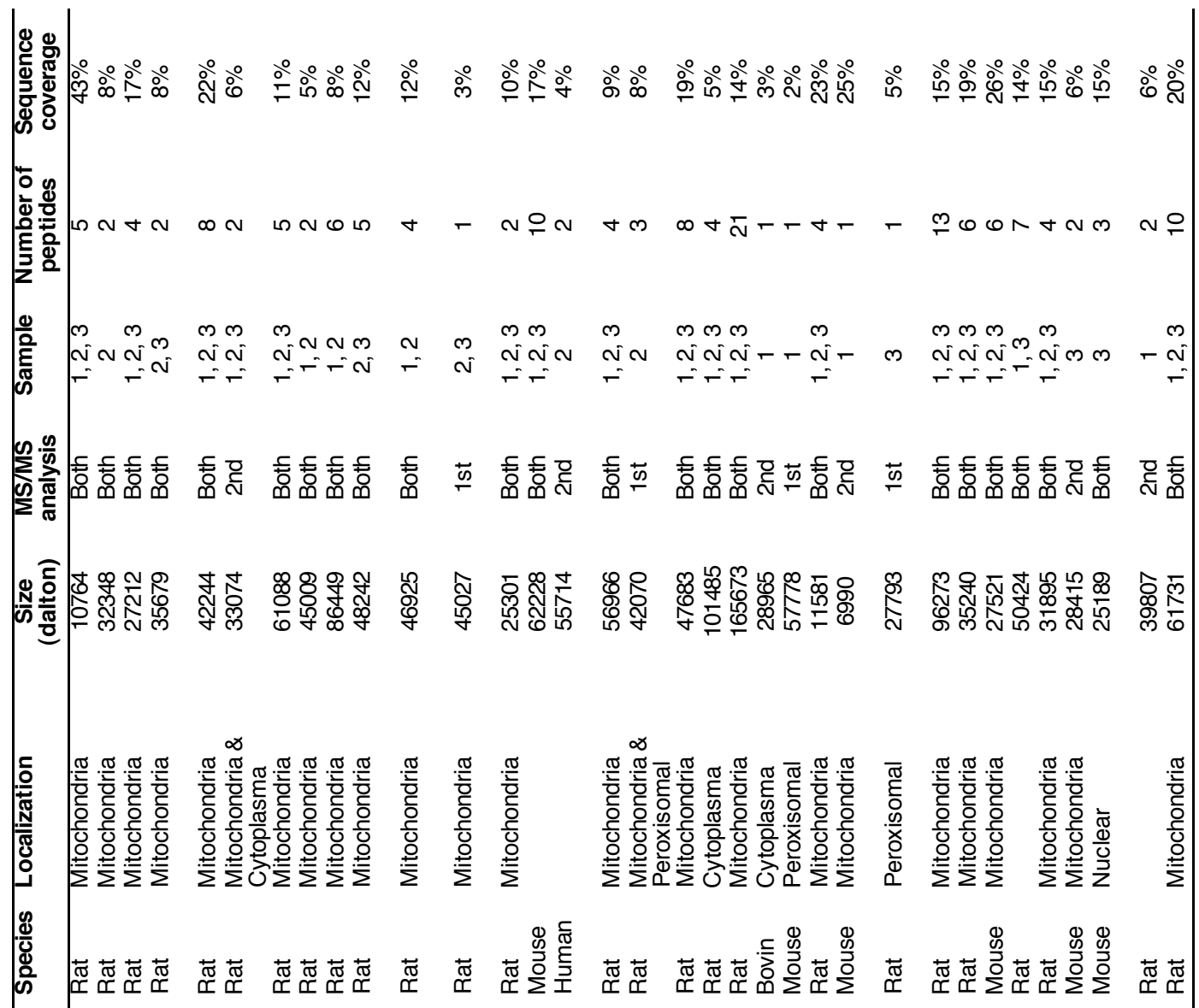

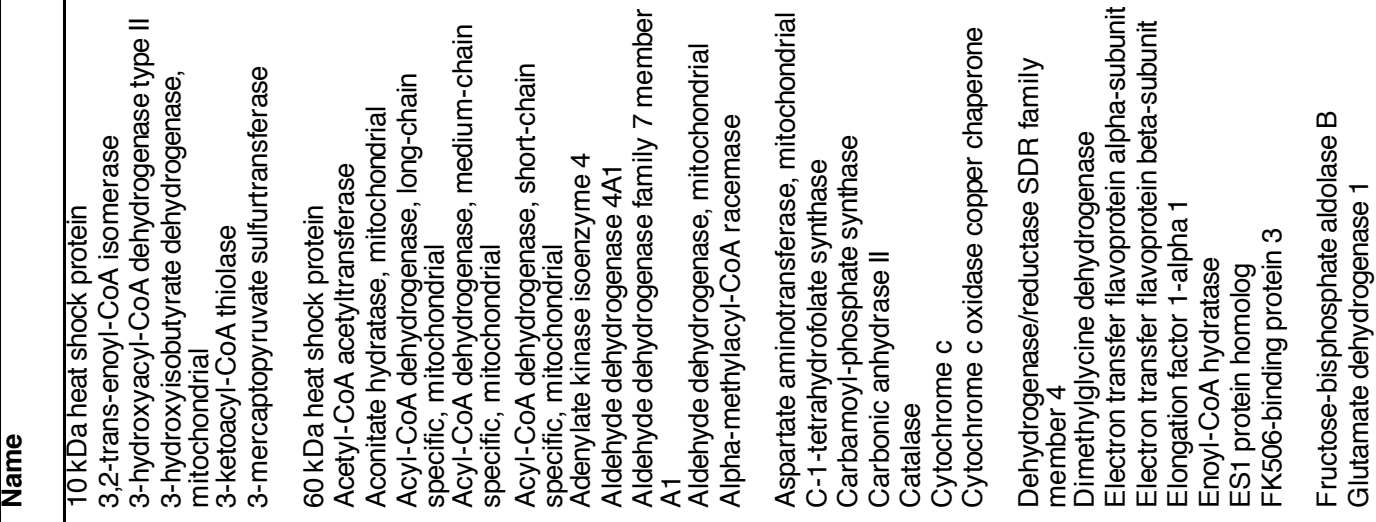

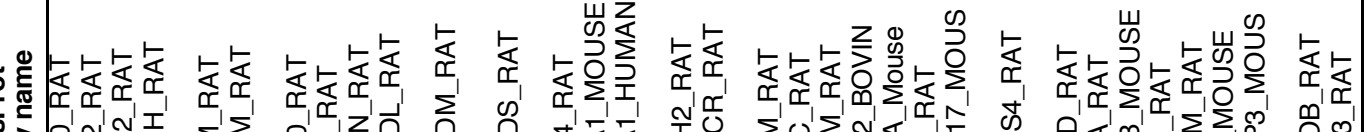

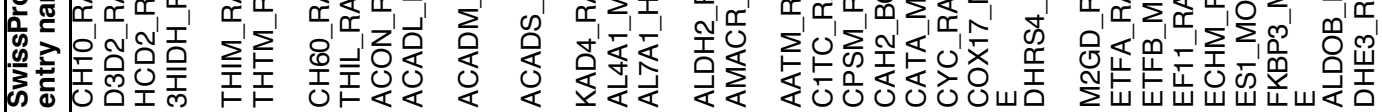

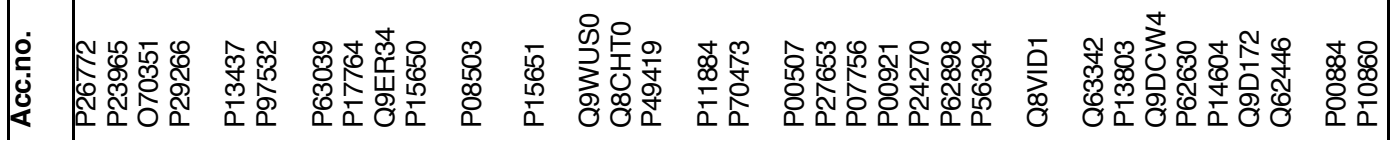




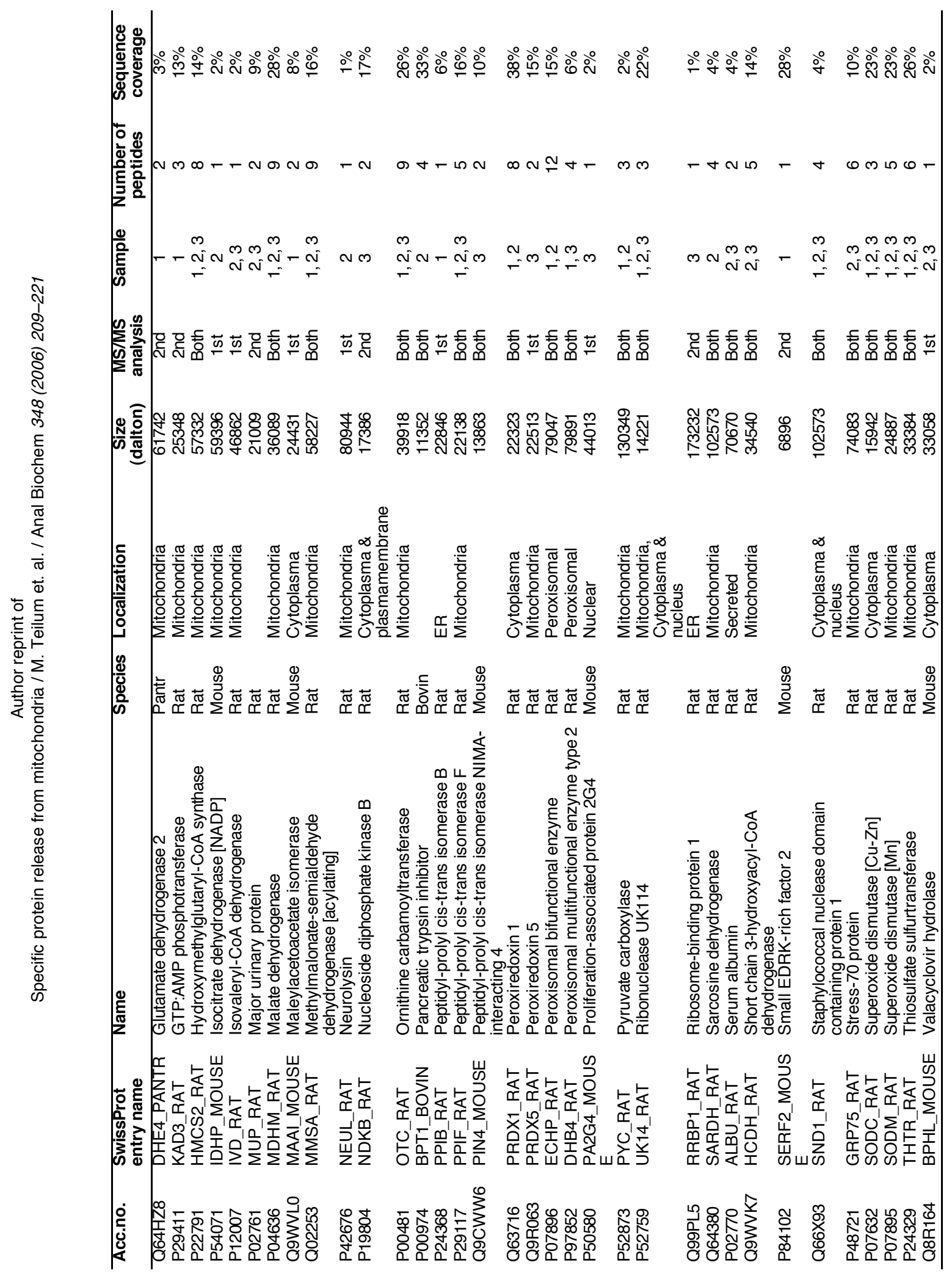

